\title{
A shift in foraging behaviour of beluga whales Delphinapterus leucas from the threatened Cumberland Sound population may reflect a changing Arctic food web
}

\author{
Cortney A. Watt ${ }^{1,2, *}$, Jack Orr $^{2}$, Steven H. Ferguson ${ }^{1,2}$ \\ ${ }^{1}$ Department of Biological Sciences, University of Manitoba, Winnipeg, MB R3T 2N2, Canada \\ ${ }^{2}$ Fisheries and Oceans Canada, 501 University Crescent, Winnipeg, MB R3T 2N6, Canada
}

\begin{abstract}
Cumberland Sound, an inlet on Baffin Island, Nunavut, Canada, is undergoing changes in sea ice cover, which is affecting the marine food web. A small population of beluga whales Delphinapterus leucas inhabits Cumberland Sound year round and this population is currently listed as threatened. Relatively little is known about the foraging behaviour of these belugas, but we expected that food web changes, primarily an increased abundance of capelin in the region, would have an impact on their diet and dive behaviour. We evaluated fatty acids in blubber samples collected from subsistence-hunted belugas in Cumberland Sound from the 1980s to 2010, and analyzed satellite tag information from 7 belugas tagged in 2006 to 2008 to gain a better understanding of their foraging behaviour. There was a change in the fatty acid profile of beluga blubber from the 1980s compared to the 1990s and 2000s. Specific fatty acids indicative of capelin and Arctic cod increased and decreased over time respectively, suggesting an increased consumption of capelin with a reduction in Arctic cod in summer in more recent years. Dive behaviour suggested different foraging tactics across seasons. Shallow short dives occurred in summer, which may indicate foraging on capelin, while deeper longer dives were made in autumn and winter, possibly indicating foraging on deeper prey such as Arctic cod and Greenland halibut. Potentially, autumn and winter are important foraging seasons for belugas, amassing energy reserves as blubber and creating a possible competitive conflict for resource use between belugas and expanding commercial fisheries.
\end{abstract}

KEY WORDS: Diet - Fatty acids - Diving - Fisheries competition - Capelin · Arctic cod · Greenland halibut

\section{INTRODUCTION}

Cumberland Sound is an inlet on the east coast of Baffin Island, Nunavut, Canada. This region is a biologically productive area and is an important summer feeding area for many animals (Cobb 2011). Beluga whales Delphinapterus leucas are ubiquitous in the Arctic, and there is a small population that inhabits Cumberland Sound year round (Richard \& Stewart 2008). Whales spend summer in the northwestern part of Cumberland Sound, particularly in Clearwater Fiord. In autumn, whales are located in the centre

\footnotetext{
*Corresponding author: cortneywatt@gmail.com
}

of the sound, and in winter belugas move towards the mouth of Cumberland Sound (Richard \& Stewart 2008). Whales in this population have been listed as threatened by the Committee on the Status of Endangered Wildlife in Canada (COSEWIC 2004) as a result of low population numbers (759 to 1960 individuals) (DFO 2005, Richard 2013, Marcoux et al. 2016). It is estimated there were $>5000$ belugas in this population prior to large commercial hunting catches between 1920 and 1960, while subsistence hunts with managed quotas have been in place since the early 1980s with hunts of $<50$ individuals per year

() C. A. Watt, S. H. Ferguson and Fisheries and Oceans Canada 2016. Open Access under Creative Commons by Attribution Licence. Use, distribution and reproduction are unrestricted. Authors and original publication must be credited.

Publisher: Inter-Research · www.int-res.com 
(Mitchell \& Reeves 1981, DFO 2002). There are also concerns regarding boat noise and competition with Greenland halibut Reinhardtius hippoglossoides fisheries, a potential prey of beluga whales (HeideJørgensen \& Teilmann 1994).

Climate change is also having impacts on the food web in Cumberland Sound. A reduction in sea ice in the Arctic has resulted in a northward shift of subarctic species that can compete with and displace Arctic species (Perovich \& Richter-Menge 2009, Tivy et al. 2011, McKinney et al. 2012). For example, in northern Hudson Bay the incidence of capelin Mallotus villosus increased from the mid-1980s to the late 1990s, with a subsequent decrease in Arctic cod Boreogadus saida (Gaston et al. 2003). Similarly, in Cumberland Sound the food web has been changing and there has been an increase in capelin and a reduction in Arctic cod (McKinney et al. 2012, Ulrich 2013). Specifically, capelin were absent in the stomachs of Arctic char Salvelinus alpinus from the Cumberland Sound region in the early 2000s, but made up the bulk of their diet in 2011, and char are known to forage opportunistically, resulting in a diet that reflects prey availability in their environment (Rikardsen et al. 2007, Ulrich 2013). These changes will undoubtedly affect the diet and behaviour of the beluga whales inhabiting the region.

Beluga whales are considered to have a more diverse diet than other Arctic cetaceans (Laidre et al. 2008). Arctic cod B. saida tends to dominate diet for belugas from the eastern Beaufort Sea (Loseto et al. 2009, Quakenbush et al. 2015) and the Canadian High Arctic (Matley et al. 2015). Pacific herring Clupea pallasii, tomcod Microgadus tomcod (Huntington \& The Communities of Buckland, Elim, Koyuk, Point Lay and Shaktoolik 1999), rainbow smelt Osmerus mordax, Arctic cod B. saida, and saffron cod Eleginus gracilis are common dietary items for different beluga stocks from Alaska (Quakenbush et al. 2015), while halibut $R$. hippoglossoides, shrimp Pandalus borealis, and redfish Sebastes marinus were found in beluga stomachs from Greenland whales (Heide-Jørgensen \& Teilmann 1994). Relatively little is known about diet from beluga whales in Cumberland Sound, but fatty acid analysis on a small number of samples $(\mathrm{n}=15)$ from 1983 to 1987 suggests that Arctic cod was prevalent in diet (Kelley et al. 2010). Stable isotope analysis on skin and muscle tissues from Cumberland Sound belugas from 2000 to 2010 suggests that diet consists primarily of Arctic cod and capelin M. villosus (Marcoux et al. 2012). Marcoux et al. (2012) also found a significant decline in $\delta^{15} \mathrm{~N}$ values from 1982 to 2009 and they suggested this decline may be a result of an increased reliance on capelin as a primary prey resource. This also correlates with evidence suggesting that capelin had low abundance in Cumberland Sound in the early 2000s, but had substantially increased in abundance by 2011 (Ulrich 2013).

Along with chemical techniques such as stable isotope and fatty acid analysis, diet can also be assessed by evaluating dive behaviour. Determining the depths to which whales are diving can provide an idea of where in the water column they are foraging and subsequently determine what common prey are available at those depths (Watt et al. 2015). No evaluation of dive behaviour with respect to bottom bathymetry has been conducted on belugas from Cumberland Sound; however, dive data from belugas in other regions has been analyzed with respect to bottom bathymetry. In the Canadian High Arctic, beluga whales have been tagged and researchers found characteristic deep dives to the bottom that they interpreted as foraging dives (Martin \& Smith 1992, 1999, Martin et al. 1998). In Hudson Bay, 2 populations of whales were found to have different dive behaviour. One of the populations used the entire water column when close to shore but spent more time close to the sea floor when offshore, while another population seemed to use the entire water column regardless of distance from shore (Bailleul et al. 2012). Other belugas tagged in Hudson Bay made consistent dives to the bottom (Kingsley et al. 2001), suggesting foraging on prey in the benthos. In the eastern Chukchi Sea, Citta et al. (2013) found no difference in the depths to which beluga whales of different sexes or ages dove, and diving depths suggested whales foraged primarily from 200 to $1000 \mathrm{~m}$. However, Hauser et al. (2015) did find differences in the diving behaviour of adult belugas versus immature whales from the eastern Chukchi Sea, with adults spending significantly more time at deeper depths. Hauser et al. (2015) were also able to correlate beluga dives to the distribution of Arctic cod and found that whales significantly targeted depths (200 to $300 \mathrm{~m}$ ) with maximum cod abundance.

Dive behaviour was investigated from 1998 to 1999 in a few beluga whales $(n=13)$ from Cumberland Sound (Heide-Jørgensen et al. 2001). Although the authors did not evaluate diving in relation to bottom bathymetry, they did determine that belugas from Cumberland Sound spend less time at the surface at night compared to day, with a trend towards more night dives, suggesting this may be an important time for foraging (Heide-Jørgensen et al. 2001). In addition, when compared to whales from other 
regions in the Canadian High Arctic, Cumberland Sound whales had higher dive rates and these rates did not seem to change seasonally, although only 4 tags recorded dive information in the winter and only for a short time (final transmission on 1 January 2000) (Heide-Jørgensen et al. 2001). There was annual variability in dive rates for Cumberland Sound whales but this was based on a very small sample size of whales tagged in only 2 yr (Heide-Jørgensen et al. 2001). No studies of recent dive behaviour for Cumberland Sound belugas have been conducted, and given the food web changes currently ongoing in the region, comparing biomarkers and dive behaviour is warranted.

The objectives of our study were to evaluate longterm diet trends of beluga whales in Cumberland Sound using fatty acid analysis and to investigate dive behaviour for whales in this region. With changes in the Cumberland Sound food web over the past $30 \mathrm{yr}$, most notably an increase in capelin abundance (McKinney et al. 2012, Ulrich 2013), we expected beluga whale diet to have changed over this time frame as belugas adapted to these changes. In particular, owing to the stable isotope evidence from belugas in Cumberland Sound that suggests a decrease in $\delta^{15} \mathrm{~N}$ and $\delta^{13} \mathrm{C}$, which was hypothesized to represent an increased reliance on capelin from 1982 to 2009 (Marcoux et al. 2012), as well as the evidence of increased capelin availability in Cumberland Sound, we hypothesized that belugas would monopolize on this newly abundant prey source, much like beluga whales in Hudson Bay have done (Kelley et al. 2010). Through an understanding of diet changes and dive behaviour we can determine how belugas are responding to an increase in capelin abundance in the region (McKinney et al. 2012, Ulrich 2013), and evaluate the importance of different seasons for foraging. This is an important step for understanding and conserving this threatened beluga population.

\section{MATERIALS AND METHODS}

\section{Blubber collection}

Blubber samples were collected from adult beluga whales by hunters from Pangnirtung, Nunavut, in Cumberland Sound $\left(65^{\circ} 13^{\prime} \mathrm{N}, 66^{\circ} 45^{\prime} \mathrm{W}\right)$ from 1984 to 2010 ( $\mathrm{n}=188$; 80 females and 108 males determined by genetic analyses). Whales were hunted opportunistically and were in good body condition (for consumption). A core of blubber tissue from the abdominal region was collected, frozen, and sent to the Freshwater Institute, Winnipeg, MB, where samples were stored at $-20^{\circ} \mathrm{C}$. Blubber was subsampled from these larger cores; a cube of blubber from the deepest (closest to the muscle) and most interior portion of the core (which excluded all exterior blubber that may have been oxidized over time) was used for analysis. Animals were aged by counting growth layer groups in an extracted tooth $(\mathrm{n}=179)$, and all these animals were $>1 \mathrm{yr}$ of age $(1-2 \mathrm{yr}, \mathrm{n}=4 ; 3-5 \mathrm{yr}$, $\mathrm{n}=9 ; 5-7 \mathrm{yr}, \mathrm{n}=17$; and $>7 \mathrm{yr}, \mathrm{n}=149$ ). We were unable to age 9 of the animals as no tooth was collected, but we assume these were also $>1 \mathrm{yr}$ of age, as larger animals are targeted by hunters.

\section{Fatty acid analysis}

A $0.5 \mathrm{~g}$ subsection of blubber was extracted from as close to the muscle as the sample allowed, and used for lipid extraction following Folch et al. (1957) and Budge et al (2006). Blubber was freeze-dried for $48 \mathrm{~h}$ before lipid extraction. Blubber was subjected to a chloroform:methanol solution (2:1) with $0.01 \%$ butylated hydroxytoluene (BHT) and then removed, and sodium chloride was added $(3.5 \mathrm{ml})$. A dichloromethane with $0.01 \%$ BHT and Hilditch (a mixture of sulfuric acid and dry methanol) solution was then added, and fatty acid methyl esters (FAME) were produced by heating the sample for $1 \mathrm{~h}$ at $100^{\circ} \mathrm{C}$. Hexane, distilled water, and sodium sulfate were added and then the sample was placed under an evaporative nitrogen stream, and the total FAME was weighted. Agilent Technologies 7890A GC system was used to analyze the FAME sample. Standards (Supelco 37 component FAME mix and Nucheck 54 component mix GLC-463) were run every tenth sample, and FAME were identified by comparison to the standards and the resulting retention times.

Many fatty acids are biosynthesized in predator tissues and are not informative for determining diet; thus, only 35 dietary fatty acids were evaluated in this study (Iverson et al. 2004). As a result of the detection limit of the gas chromatography, some individuals are interpreted as having $0 \%$ of a given fatty acid; in these cases, an arbitrary small number (0.00001) was added (Kenkel 2006). Percent fatty acid values were divided by the percentage of the reference fatty acid C18:0 and log transformed (Budge et al. 2006). To calculate precision, 23 samples were run in duplicate with an average standard deviation of $0.04 \pm 0.08 \%$ (average $\mathrm{SD} \pm \mathrm{SD}$ ). 
A principal component analysis (PCA) of the 35 dietary fatty acids was used to reduce the dimensionality of the log-transformed data to a few uncorrelated dimensions, and the first 2 principal components were used in further analysis. Principle components were then input into a multivariate analysis of variance (MANOVA) to determine if beluga fatty acid values varied over time period (1980-1989, 19901999, and 2000-2010) or between sexes. Pillai's trace was used to determine significance for each of the factors because it is considered the most powerful and robust MANOVA statistic (Olson 1974). A canonical plot with scores obtained from a discriminant analysis on the principal components was used to graphically display the multivariate fatty acid data. Regression analysis was used to investigate how specific fatty acids changed over time. Although we did not have a prey library to specifically compare beluga fatty acid signatures over time to those of potential prey, there is evidence that whales in this population forage primarily on capelin and Arctic cod (Marcoux et al. 2012), at least in the summer months. Kelley et al. (2010) compared fatty acid signatures of capelin and Arctic cod using a PCA. The PCA identified 5 dietary fatty acids representative of Arctic cod (20:1n7, 20:1n9, 22:1n9, 22:1n11, and 22:1n7) and 4 representative of capelin $(18: 2 \mathrm{n} 6,22: 6 \mathrm{n} 3,22: 5 \mathrm{n} 6$, and 20:4n6) (Kelley et al. 2010). $t$-tests confirmed that the fatty acids were significantly different between Arctic cod and capelin ( $\mathrm{p} \leq 0.001$ ) (Kelley et al. 2010). As we were particularly interested in investigating dietary shifts over time from Arctic cod to capelin, a regression analysis with each fatty acid as a dependent variable and year as an independent variable was investigated.

\section{Dive behaviour}

Satellite-linked time-depth recorder tags (SPLASH tags, Wildlife Computers) were deployed on adult beluga whales to transmit daily information on their location and diving behaviour. A total of 7 belugas, 5 females and 2 males, were tagged in Cumberland Sound (66 $\left.16^{\prime} 18^{\prime \prime} \mathrm{N}, 67^{\circ} 05^{\prime} 90^{\prime \prime} \mathrm{W}\right)$, near the community of Pangnirtung, Nunavut, in July $2006(\mathrm{n}=1)$, August 2007 ( $\mathrm{n}=2$ ), and September 2008 ( $\mathrm{n}=4$ ) (Fig. 1, Table 1). Methods for beluga capture and tagging have previously been published (Orr et al. 2001). In short, belugas were captured in nets set perpendicular to the shore from a small island along the migratory route of the whales on a daily basis, as weather permitted. Once caught, 2 inflatable zodiac boats with at least 3 passengers would travel out to the net, pull the whale to the surface and hold it between the 2 boats for instrumentation with a satellite-linked transmitter. The whales were held in place with a hoop net over the head, 3 to 4 straps along their body, and a rubberized rope around the tailstock, which were all tied to loops on the boats.

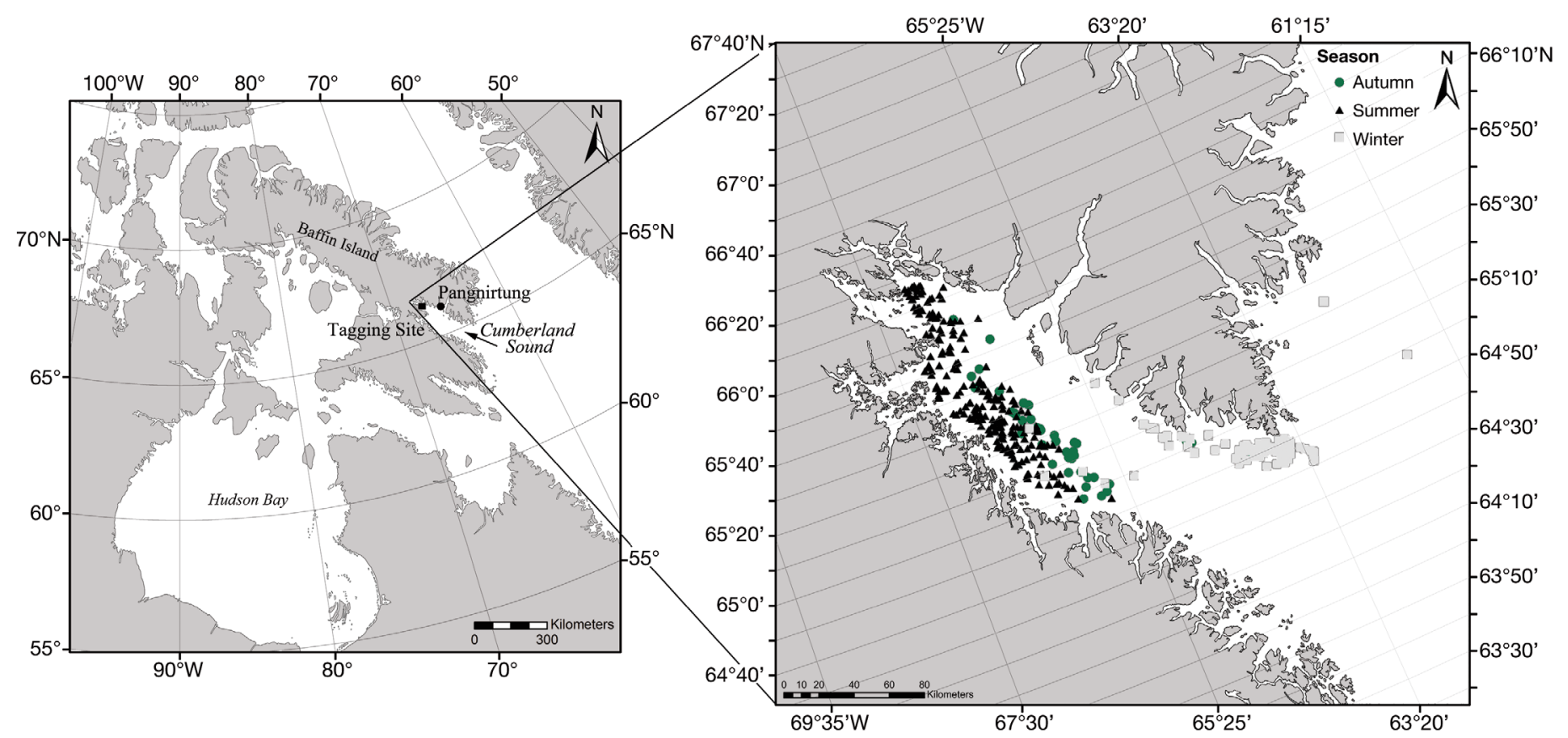

Fig. 1. Tagging site ( $\square$ ) and the closest community, Pangnirtung, Nunavut (•), where beluga whales were tagged in 2006 to 2008, and the locations where Cumberland Sound belugas were diving $>50 \mathrm{~m}$ in summer, autumn, and winter 
Table 1. Deployment date, sex, approximate length, the number of $6 \mathrm{~h}$ blocks for dive depth and dive duration collected, and the number of days dive information was transmitted for each season for beluga whales deployed with satellite-linked transmitters from 2006 to 2008 in Cumberland Sound. Dates given as mm/dd/yy

\begin{tabular}{|c|c|c|c|c|c|c|c|c|}
\hline \multirow{2}{*}{$\begin{array}{l}\text { Deployment } \\
\text { date }\end{array}$} & \multirow[t]{2}{*}{ Sex } & \multirow[t]{2}{*}{ Tag no. } & \multirow{2}{*}{$\begin{array}{l}\text { Length } \\
\text { (cm) }\end{array}$} & \multicolumn{3}{|c|}{ No. of $6 \mathrm{~h}$ blocks (dive depth/duration) } & \multirow{2}{*}{$\begin{array}{l}\text { Date of last dive } \\
\text { data transmission }\end{array}$} & \multirow{2}{*}{$\begin{array}{c}\text { Transmission } \\
\text { length (d) }\end{array}$} \\
\hline & & & & Summer & Autumn & Winter & & \\
\hline 07/18/06 & $\mathrm{F}$ & 57594 & - & $42 / 44$ & $20 / 24$ & $42 / 38$ & 03/01/07 & 226 \\
\hline 07/12/07 & $\mathrm{F}$ & 57602 & 350 & $104 / 110$ & $8 / 13$ & $0 / 0$ & $10 / 29 / 07$ & 109 \\
\hline $07 / 12 / 07$ & $\mathrm{~F}$ & 37023 & 315 & $58 / 60$ & $17 / 19$ & $0 / 0$ & $10 / 24 / 07$ & 104 \\
\hline 09/06/08 & $\mathrm{F}$ & 39296 & 290 & $45 / 48$ & $14 / 32$ & $50 / 79$ & 05/09/09 & 246 \\
\hline $09 / 05 / 08$ & $\mathrm{~F}$ & 39308 & 340 & $41 / 45$ & $14 / 24$ & $85 / 112$ & $05 / 11 / 09$ & 249 \\
\hline 09/09/08 & $\mathrm{M}$ & 39323 & 370 & $48 / 50$ & $18 / 34$ & $72 / 66$ & $04 / 18 / 09$ & 222 \\
\hline 09/09/08 & $\mathrm{M}$ & 40623 & 340 & $2 / 3$ & $0 / 0$ & $0 / 0$ & 09/13/08 & 4 \\
\hline
\end{tabular}

Three $10 \mathrm{~mm}$ nylon pins were then placed through the dorsal ridge and the tag was anchored to the pins with high-grade stainless steel wires looped around specially designed washers.

The Argos system (CLS America) was used to obtain location data. Locations were summarized into four $6 \mathrm{~h}$ histograms, referred to from their starting time, i.e. 02:00, 08:00, $14: 00$ and 20:00 h local time at deployment location, every day throughout the months of July through September, and every fourth day from October through June. All tags provided the mean number of dives belugas made to different dive duration bins, and the number of dives to different depth bins for each $6 \mathrm{~h}$ period. The proportion of time spent in different depth bins was also collected, but owing to the configurations of the tags, the maximum depth evaluated was $200 \mathrm{~m}$ and thus was not particularly relevant for this study. The tags provide a depth resolution of $0.5 \mathrm{~m}$ (Wildlife Computers) and all tags were programmed with the same bins; the number of dives to different depths were binned into $6,8,10,12,15,20,25,50,100,200,300,400,500$, and $>500 \mathrm{~m}$ bins, and mean number of dives made to different dive duration bins were binned into 60,180 , $360,540,720,900,1080,1260,1440$, and $>1440$ s bins (Wildlife Computers). The accuracy of the transmissions was used to categorize the location information. Categories A and B provide no location information; Class 0 represents an error of $>1500 \mathrm{~m}_{\text {; Class } 1,500-}$ $1500 \mathrm{~m}_{i}$ Class 2, 250-500 m; and Class 3, <250 m (CLS America).

Even when dive information was provided for the previous $6 \mathrm{~h}$, often the location associated with it was of low quality. As we wanted to use the location data to assign a depth to each dive, we needed a valid estimate of all locations. We generated locations evenly spaced in time that considered the quality of the location from Argos using the Jonsen et al. (2005) estimation method. As the tags were programmed to provide dive information for $6 \mathrm{~h}$ increments every day from July to September, a time step of $6 \mathrm{~h}$ was used to generate locations for this time period, while a time step of $4 \mathrm{~d}$ was used for transmission from October to June. The International Bathymetric Chart of the Arctic Ocean (IBCAO) provided shape files of ocean bathymetry with $500 \mathrm{~m}^{2}$ resolution (Jakobsson et al. 2012), which were projected using a North Pole projection in ArcGIS and were used to assign a depth for each location (Fig. 1).

After bathymetry data was obtained for each location, we isolated the dive depth bins that we were interested in to evaluate foraging (>50 m deep). We used deep diving as a proxy for marine mammal foraging, as deep dives are often associated with prey capture (Davis et al. 2013). We assumed dives $<10 \mathrm{~m}$ were associated with surface behaviours (Citta et al. 2013) and that dives from the 10 to $50 \mathrm{~m}$ depth layer may represent transit or recovery diving (Hauser et al. 2015). In addition, although some foraging may occur at shallower depths, the main prey items for Cumberland Sound beluga whales determined by stable isotope analysis are capelin and Arctic cod, and adults of these species are typically found at depths $>50 \mathrm{~m}$ (Falk-Petersen et al. 1986, Brown 2002, Christiansen et al. 2012, Hauser et al. 2015) (see 'Discussion' for further details). Depth bins representing dives deeper than $50 \mathrm{~m}$ were then converted to a percentage of total depth for each location and grouped into different dive depth categories (Watt et al. 2015): dives that occurred in the upper $25 \%$ of total depth, those that occurred from $26-50 \%$, from $51-75 \%$ of total water depth, and those dives that occurred in the lower $76-100 \%$ of the total depth. There is uncertainty in the depth estimates at these locations, and because of this, dives sometimes exceeded the IBCAO depths; in these cases, dives were included in the $76-100 \%$ category. The average depth at which whales were making dives $>50 \mathrm{~m}$ did not vary signif- 
icantly across seasons. In summer, the average bathymetric depth at which whales were diving $>50 \mathrm{~m}$ was $247 \mathrm{~m}$ (range 75 to $652 \mathrm{~m}$ ), compared to autumn, when whales were in waters averaging $378 \mathrm{~m}$ depth (range 85 to $617 \mathrm{~m}$ ), and winter, where average depth was $230 \mathrm{~m}$ (range 77 to $581 \mathrm{~m}$ ).

Unfortunately, we did not have a large enough sample size of males ( $\mathrm{n}=2$, with 1 tag only lasting $7 \mathrm{~d}$ ) to evaluate if different sexes have different dive behaviours. However, we did evaluate how the number of dives differed across seasons using repeated-measures ANOVAs. Seasons were defined based on previous tracking data of beluga whales from Cumberland Sound: July to September was identified as summer, October and November as autumn, and December to May as winter (Richard \& Stewart 2008) (Fig. 1). One model considered individual whales nested within each season as a random effect, and season (3 levels: summer, autumn, and winter), depth (number of dives $>50$ m deep made to $0-25,26-50,51-75$, and $76-100 \%$ of total depth and 50-100, 100-200, 200-300, 300-400, $400-500$, and $>500 \mathrm{~m}$ ), and the interaction between these factors as main effects (Underwood 1997). Repeated-measures ANOVA was also used to evaluate dive duration where individual whales were nested within each season as a random effect, and season (3 levels: summer, autumn, and winter), dive duration $(60,180,360,540,720,900,1080,1260,1440$, and $>1440 \mathrm{~s}$ ), and the interaction between these factors as main effects (Underwood 1997).

Normality was assessed with normal probability plots, and a Box-Cox transformation was used on dive depth and duration data to improve normality (Box \& Cox 1964). The Mauchly criterion (Mauchly 1940) was used to assess sphericity and, when the sphericity assumption was violated, adjusted Greenhouse-Geisser degrees of freedom were used. This adjustment multiplies the calculated epsilon by the original degrees of freedom to create a more conservative test (Greenhouse \& Geisser 1959). Depth and dive duration were considered repeated-measures factors because bins were not independent of one another, and the nested nature of the design accounted for within-subject variability (Underwood 1997). When a significant interaction was found in the main effects model (described above) between season and depth/dive duration, a simple effects model for each depth/dive duration category with individual whales nested within each season as a random effect and season as a fixed factor was analyzed. When significant factors were identified, post-hoc Tukey's HSD tests were used to determine where significant differences occurred. R and JMP 9.0 software were used for all statistical tests.

\section{RESULTS}

\section{Fatty acid analysis}

The first 2 principal components from the 35 dietary fatty acids explained $55 \%$ of the variability in the data. A MANOVA on the first 2 principal components found no significant interaction between sexes and year category $\left(F_{4,364}=1.70, \mathrm{p}=0.15\right)$ or between sexes $\left(F_{2,181}=2.27, \mathrm{p}=0.11\right)$, but found a significant effect of time period $\left(F_{4,364}=3.40, p<0.01\right)$ (Fig. 2). Linear regression analysis of the 5 fatty acids representative of Arctic cod revealed that from 1984 to 2010 there was a downward trend for all fatty acids $\left(20: 1 \mathrm{n} 7: y=-0.004 x+6.82\right.$, adjusted $\mathrm{R}^{2}=0.00, \mathrm{SE}=$ 0.30; 20:1n9: $y=-0.01 x+17.40$, adjusted $\mathrm{R}^{2}=0.01$, $\mathrm{SE}=0.35 ; 22: 1 \mathrm{n} 7: y=-0.02 x+38.98$, adjusted $\mathrm{R}^{2}=$ $0.06, \mathrm{SE}=0.47 ; 22: 1 \mathrm{n} 9: y=-0.02 x+33.61$, adjusted $\mathrm{R}^{2}=0.06, \mathrm{SE}=0.39 ; 22: 1 \mathrm{n} 11: y=-0.01 x+29.77$, adjusted $\mathrm{R}^{2}=0.05, \mathrm{SE}=0.37$, and this trend was significant for 3 of the fatty acids (22:1n9: $F_{1,186}=12.85$, $\mathrm{p}<0.001 ; 22: 1 \mathrm{n} 11: F_{1,186}=9.87, \mathrm{p}<0.01 ; 22: 1 \mathrm{n} 7$ : $F_{1,186}=12.98, \mathrm{p}<0.001$ ) (Fig. 3). Regression analysis on the 4 dietary fatty acids representative of capelin

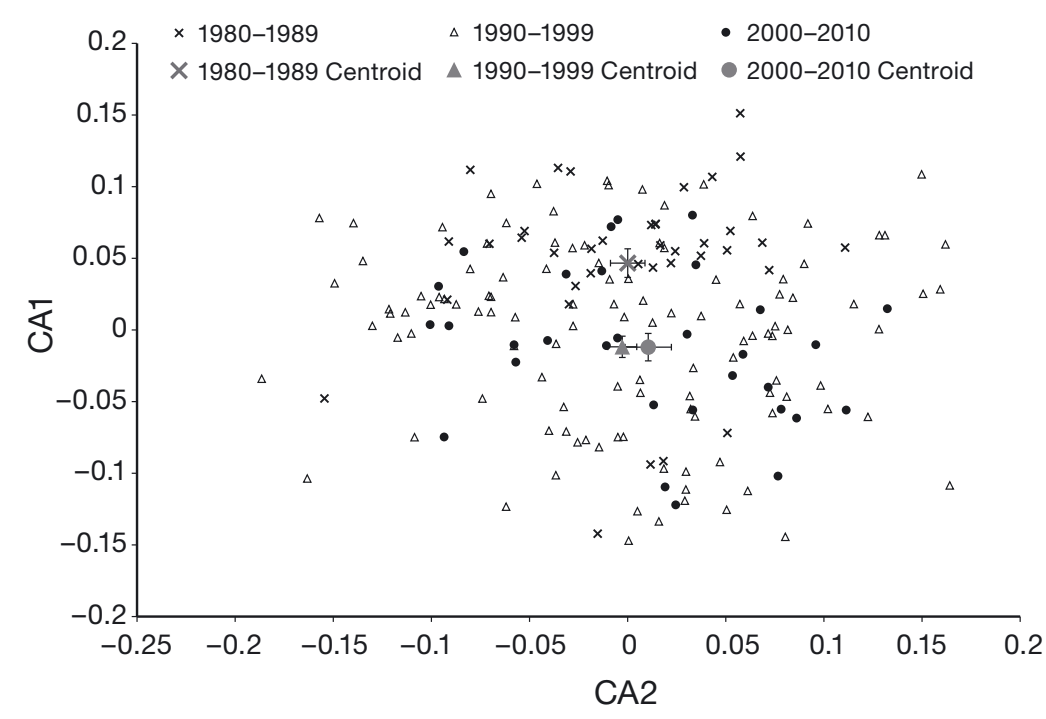

Fig. 2. Canonical plot of beluga fatty acids from 3 time periods, 1980-1989 (number of whales sampled = 38), 1990-1999 $(\mathrm{n}=119)$, and 2000-2010 (n = 31). Centroids $\pm \mathrm{SE}$ are plotted for each time period 
found a positive trend for all fatty acids (22:6n3: $y=0.02 x-31.10$, adjusted $R^{2}=$ $0.02, \mathrm{SE}=0.51 ; 18: 2 \mathrm{n} 6: y=0.02 x-40.45$, adjusted $\mathrm{R}^{2}=0.06, \mathrm{SE}=0.53 ; 20: 4 \mathrm{n} 6: y=$ $0.02 x-33.51$, adjusted $\mathrm{R}^{2}=0.09, \mathrm{SE}=$ $0.41 ; 22: 5 n 6 ; y=0.01 x-27.26$, adjusted $\mathrm{R}^{2}=0.00, \mathrm{SE}=2.70$ ), which was significant for 3 of them (18:2n6: $F_{1,186}=12.13$, $\mathrm{p}<0.001 ; 22: 6 \mathrm{n} 3: F_{1,186}=4.15, \mathrm{p}<0.05$; 20:4n6: $F_{1,186}=19.23, \mathrm{p}<0.0001$ ) (Fig. 4).

\section{Dive behaviour}

The full factorial repeated-measures ANOVA on the number of dives $>50 \mathrm{~m}$ made with respect to depth found a significant interaction between season and depth category $\left(F_{5,1814}=4.97, \mathrm{p}<\right.$ $0.001)$. Models for each depth category found a significant effect of season for $0-25 \%$ depth $\left(F_{2,403}=6.33, \mathrm{p}<0.01\right)$, $26-50 \%\left(F_{2,438}=8.10, \mathrm{p}<0.001\right), 51-$ $75 \%\left(F_{2,411}=4.82, \mathrm{p}<0.01\right)$, and $76-$ $100 \%\left(F_{2,451}=3.43, \mathrm{p}=0.03\right)$ (Fig. $\left.5 \mathrm{~A}\right)$. There were significantly more dives $>50 \mathrm{~m}$ in autumn to $0-25 \%$ of total depth, and less dives in winter to 26$75 \%$ of total depth (Fig. 5A). More deep dives were made to $76-100 \%$ of total depth in winter compared to summer (Fig. 5A). The full factorial repeated-measures ANOVA on the number of dives made to different depth bins found a significant interaction between season and depth category $\left(F_{8,2440}=19.24, \mathrm{p}<0.001\right)$. Models for each depth category found a significant effect of season for all depths (50-100 m: $\left.F_{2,406}=23.50, \mathrm{p}<0.0001\right)$; $100-200 \mathrm{~m}: F_{2,272}=10.76, \mathrm{p}<0.0001 ; 200-300 \mathrm{~m}:$ $F_{2,399}=7.59, \mathrm{p}<0.001 ; 400-500 \mathrm{~m}: F_{2,406}=30.42, \mathrm{p}<$ $\left.0.0001 ;>500 \mathrm{~m}: F_{2,300}=38.42, \mathrm{p}<0.0001\right)$, except $300-400 \mathrm{~m}\left(F_{2,406}=2.67, \mathrm{p}=0.07\right)$ (Fig. 5B). There were significantly more dives to shallower depths in summer (50-100 and 200-300 m) and significantly fewer dives to deep depths $(400-500$ and $>500 \mathrm{~m})$ compared to autumn and winter (Fig. 5B).

The full factorial repeated-measures ANOVA on number of dives of different durations found a significant interaction between season and dive duration $\left(F_{3,1225}=141.33, \mathrm{p}<0.0001\right)$. Models for each dive duration category found a significant effect of season

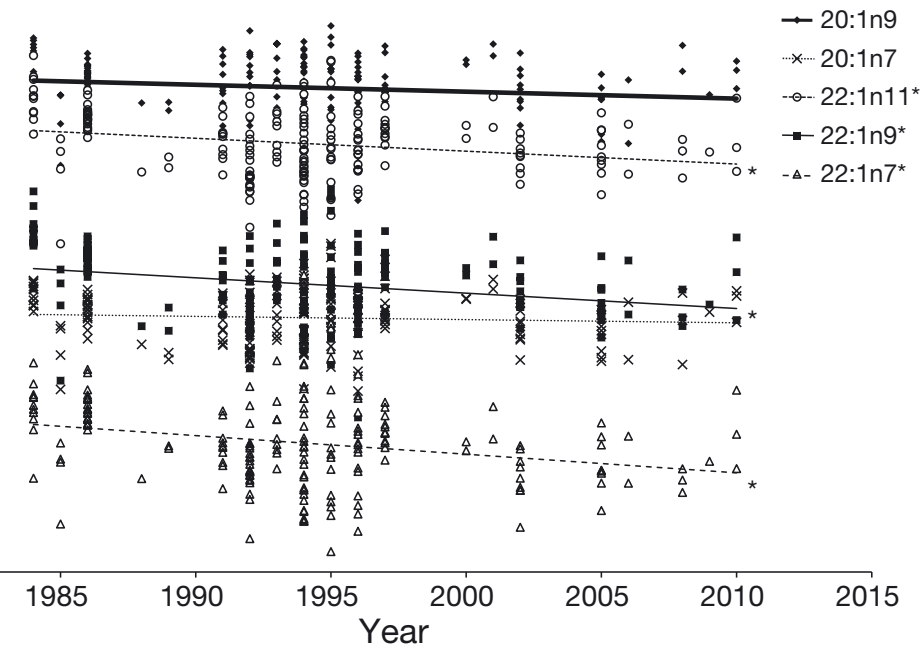

Fig. 3. Correlation between the transformation ( $\ln [\%$ FA/18:0]) of each of the 5 dietary fatty acids (FA) that are representative of Arctic cod over time with least squares regression lines. ${ }^{*}$ Significantly different at $\mathrm{p}<0.01$

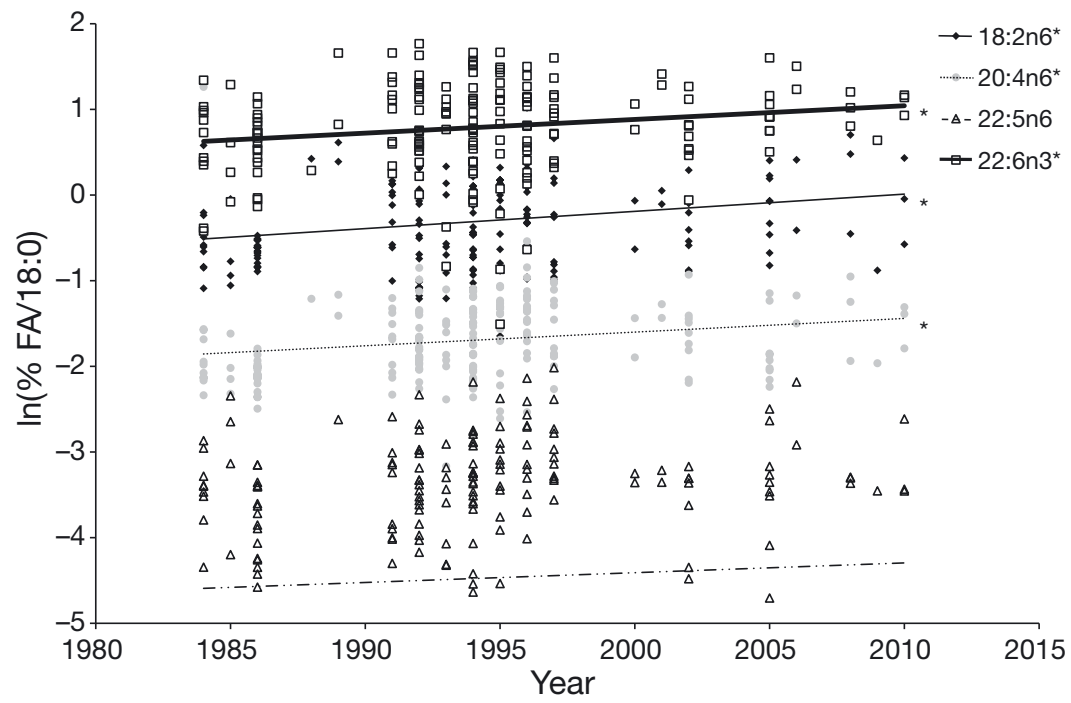

Fig. 4. Correlation between the transformation (ln[\% FA/18:0]) of each of the 4 dietary fatty acids (FA) that are representative of capelin with least squares regression lines. ${ }^{*}$ Significantly different at $\mathrm{p}<0.05$

for $0-60 \mathrm{~s}\left(F_{1,122}=7.14, \mathrm{p}<0.01\right), 61-180 \mathrm{~s}\left(F_{1,122}=\right.$ $46.25, \mathrm{p}<0.0001), 181-360 \mathrm{~s}\left(F_{1,11}=69.87, \mathrm{p}<\right.$ $0.0001), 361-540 \mathrm{~s}\left(F_{1,106}=22.54, \mathrm{p}<0.0001\right), 541-$ $720 \mathrm{~s}\left(F_{1,118}=51.28, \mathrm{p}<0.0001\right), 721-900 \mathrm{~s}\left(F_{1,121}=\right.$ 432.06, $\mathrm{p}<0.0001)$, and 901-1080 s $\left(F_{1,115}=326.66\right.$, $\mathrm{p}<0.0001$ ) (Fig. 6). In general, short dives were more frequent in summer and autumn compared to winter, while dives of longer duration were more prominent in winter, with few of these dives made in summer (Fig. 6). It was not possible to run simple effects models for dive duration in the 1260,1440, and $>1440 \mathrm{~s}$ bins because in these cases only a few whales ever made dives this long, and they were usually in 1 season 

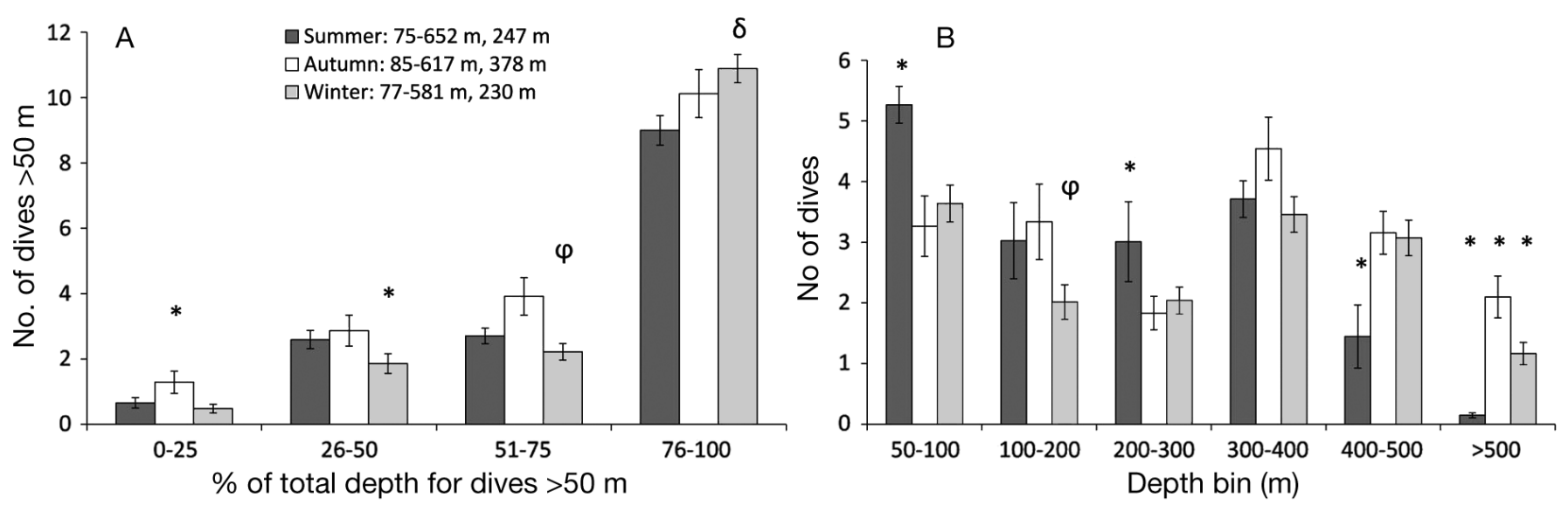

Fig. 5. Mean number of dives $( \pm \mathrm{SE})$ made to different depth categories for beluga whales from Cumberland Sound in summer (number of $6 \mathrm{~h}$ blocks collected $=232)$, autumn $(\mathrm{n}=83)$, and winter $(\mathrm{n}=208)$. (A) Number of dives $>50 \mathrm{~m}$ deep in relation to bottom bathymetry. (B) Number of dives made to different programmed dive depth bins. ${ }^{*}$ Levels of significance vary (see 'Results'); least significance is $\mathrm{p}<0.01 ; \varphi$ indicates a significant difference between winter and autumn, but no significant difference between winter and summer, and $\delta$ indicates a significant difference between winter and summer, but no significant difference between winter and autumn. The range of depths encountered by beluga whales in each season is shown in the key, along with the average depth encountered

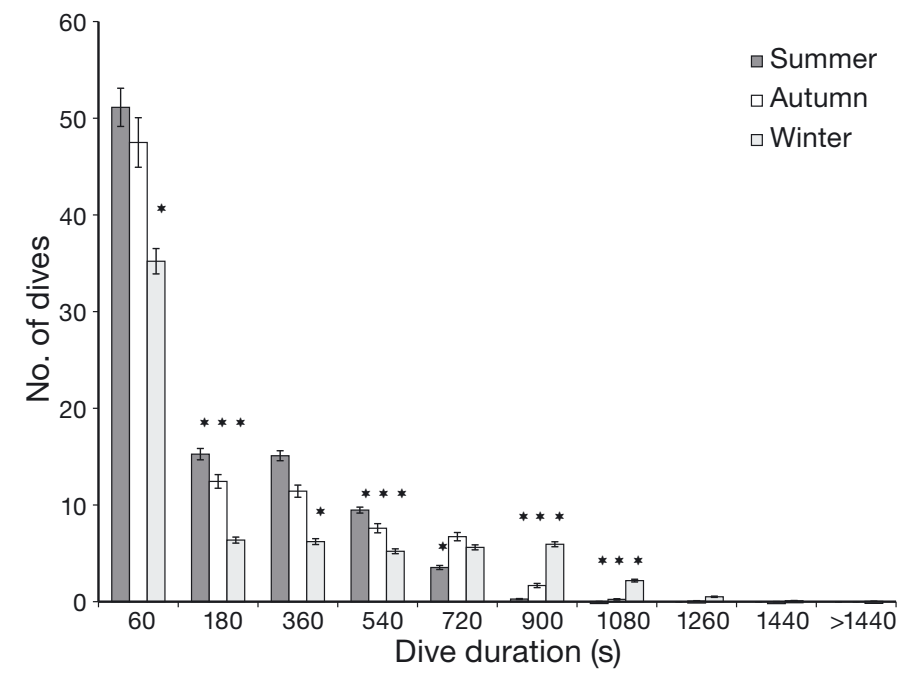

Fig. 6. Mean number of dives $( \pm \mathrm{SE})$ made to different dive duration categories for beluga whales from Cumberland Sound in summer (number of $6 \mathrm{~h}$ blocks collected $=360)$, autumn $(\mathrm{n}=$ 146), and winter $(\mathrm{n}=295)$. ${ }^{*}$ Levels of significance vary (see 'Results'); least significance is $\mathrm{p}<0.01$

(winter). For instance, only 1 whale (39323 = 10 dives) made dives to the $>1400 \mathrm{~s}(23 \mathrm{~m})$ duration dive bin, and these dives were only made in winter. Only 3 whales $(39296=5$ dives, $39323=22$ dives, and 57594 $=2$ dives) made dives to the 1261-1400 s dive bin, all in winter. Ten dives were made in autumn by 2 whales ( $39323=6$ dives and $57594=4$ dives) to the 1081-1260 s dive duration category, while 150 dives were made to this category in winter by 4 whales (57594 = 18 dives, $39323=94$ dives, $39308=10$ dives, and $39296=28$ dives).

\section{DISCUSSION}

Beluga whales in Cumberland Sound have experienced a change in their fatty acid values since the 1980s and seem to have increased their consumption of capelin, while decreasing reliance on Arctic cod over the past 3 decades. Fatty acids in blubber represent diet over the previous few weeks (Kirsch et al. 2000, Iverson et al. 2004, Budge et al. 2006), and all samples (except 5 that were collected in winter) used in this study were collected in summer (June to September); thus, fatty acids represent primarily a summer diet signature for this group of whales. This suggests that capelin consumption in summer months has been increasing while cod consumption has been decreasing; however, explained variation was low. Stable isotopes, which represent diet integrated over a longer time span (2 to 3 mo for skin and several months for muscle; St. Aubin et al. 1990, Sponheimer et al. 2006), in Cumberland Sound beluga skin and muscle have also changed since the 1980s, which may be attributed to increasing capelin consumption (Marcoux et al. 2012).

The primary fatty acids that distinguish Arctic cod from capelin (Kelley et al. 2010) were evaluated to see specifically if the significant change in fatty acid signatures from the 1980s could be attributed to changes in cod and capelin consumption; however, inferring diet from only a few fatty acids can be problematic (Budge et al. 2006). Unfortunately, we did not have fatty acid profiles from cod and capelin from Cumberland Sound for 1980 to 2010 to compare to 
the beluga values and obtain an estimate of cod and capelin consumption. Although this would have been ideal, it would have required a long-term monitoring project in Cumberland Sound that began in the 1980s. As this was not possible, we believe it is useful to at least investigate the fatty acids that seem to decipher Arctic cod from capelin, particularly since there is evidence that the 2 species make up the majority of summer diet for Cumberland Sound belugas (Marcoux et al. 2012). The Arctic cod and capelin samples collected by Kelley et al. (2010) came from different locations: cod was collected in the high Arctic, while capelin was collected in Hudson Bay. In addition, explained variation was low and beluga metabolism may affect fatty acids differently (Iverson et al. 2004). As a result, the interpretation that there is an increasing trend in fatty acids distinctive for capelin and that a decreasing trend is common in Arctic cod should be interpreted with caution; however, our study does support a shift in the dietary fatty acid profiles of beluga whales since the 1980s that is concurrent with an invasion of capelin in Cumberland Sound (Ulrich 2013).

Our dive data represents information from only 7 beluga whales (1 tag lasting only $4 \mathrm{~d}$ ) that were tagged over 3 yr with males being tagged in only 1 of those years. We are using these whales to represent a population that is much larger ( 1150 individuals; Marcoux et al. 2016), and although we can account for individual variability in dive behaviour by using a nested statistical model, we were not able to evaluate differences owing to year or sex. As a result, we recommend caution in interpreting the dive data while balancing the valuable insight provided by data that is logistically difficult and expensive to obtain.

Generally, it is difficult to decipher the importance of Arctic cod versus capelin in diet from dive behaviour, as the 2 fish species have overlapping geographic distributions (Orlova et al. 2009), and unfortunately there is little information about the depths at which Arctic cod and capelin distribute within Cumberland Sound, particularly as capelin is a relatively new species in this ecosystem (Ulrich 2013). However, there is data on the depth distribution of the 2 species in other areas in the Arctic and they are known to distribute at different depths. Arctic cod are considered a semi-pelagic species as young are found in the pelagic zone, but adults are found near the bottom (Falk-Petersen et al. 1986, Majewski et al. 2016). Belugas in the Canadian High Arctic typically select larger Arctic cod as prey ( 180 to $200 \mathrm{~mm}$ ) (Matley et al. 2015), and prey of this size class are typically found at depths of 200 to $400 \mathrm{~m}$ (Falk-
Petersen et al. 1986, Christiansen et al. 2012, Hauser et al. 2015, Majewski et al. 2016). Capelin, on the other hand, are found in shallower waters, typically from 50 to $100 \mathrm{~m}$ in the Gulf of Alaska (Brown 2002), and capelin found in stomachs of belugas from Alaska measured an average of $124 \mathrm{~mm}$ in length (Quakenbush et al. 2015). If this trend is the same for belugas in Cumberland Sound, dives from 50 to $100 \mathrm{~m}$ were the most frequent type of deep dive and occurred primarily in the summer months, whereas deeper dives (300 to $400 \mathrm{~m}$ ) occurred in all seasons. This may suggest that capelin is dominating diet in the summer, while Arctic cod is more prevalent in the autumn and winter seasons.

When dives were evaluated in relation to bottom bathymetry, dives to the 76-100\% category were still the most prevalent in summer (although less common than in autumn or winter). Whales make most of their dives in the summer at 50 to $400 \mathrm{~m}$. As a result of the binning of the dive depths, a dive that fell into the 100-200 m bin, for example, was counted as a $200 \mathrm{~m}$ dive for the purposes of confirming the number of dives to the different categories of the water column. Since the average summer depth is only $247 \mathrm{~m}$, any dive that fell in a bin deeper than 50-100 m would be in the $76-100 \%$ category. Only those dives that fell into the 50-100 $\mathrm{m}$ depth bin would fall into the other 3 portions of the water column. The binning of the dive data, as well as the uncertainty with the bottom depths in this region, may be influencing how the dive behaviour distributes across the depth categories; however, since larger capelin tend to school at 50 to $100 \mathrm{~m}$, and this is where the most dives are occurring based on the absolute dive depths, it is possible that belugas may be foraging on this newly available prey source. Belugas also seem to be diving to depths of 100 to $400 \mathrm{~m}$ fairly frequently in summer, which may also indicate some foraging on Arctic cod at these depths and would be in line with the foraging results from stable isotopes (Marcoux et al. 2012).

The deepest dives (those $400 \mathrm{~m}$ and greater) were prevalent in autumn and winter, and belugas made more dives to the $76-100 \%$ depth category and dives of longer duration in winter compared to summer or autumn. Greenland halibut has been found in the stomachs of beluga whales from Greenland (HeideJørgensen \& Teilmann 1994) and is a deep benthic species with adults $(50$ to $60 \mathrm{~cm}$ ) found at depths of between 800 and $1200 \mathrm{~m}$ in Cumberland Sound (DFO 2008, Dennard et al. 2009, 2010). The programming design of the tags used on belugas in Cumberland Sound from 2006 to 2008 did not allow us to separate any dives $>500 \mathrm{~m}$, but it is unlikely that whales 
would make such energetically expensive dives in the winter for any reason other than foraging. Unfortunately, fatty acids from this study and stable isotopes from Marcoux et al. (2012) were not able to evaluate winter feeding, as samples were collected primarily in later summer months and thus did not integrate winter diet; however, based on our dive data, it does seem that dive behaviour supports foraging on Greenland halibut, and future studies would benefit from collecting beluga blubber samples (e.g. biopsy) year round.

Cumberland Sound is an important region for marine mammals and provides a number of resources to the community of Pangnirtung. Beluga whales are an important part of this ecosystem and are currently a threatened species (COSEWIC 2004). Our study, as well as results from stable isotopes (Marcoux et al. 2012), suggests beluga whales are incorporating both Arctic cod and capelin in their diet, but summer capelin consumption may be increasing. A switch from Arctic cod to capelin is likely inconsequential for the energy budget of beluga whales, as both capelin and Arctic cod have high caloric values (Hop \& Gjøsæter 2013); however, the energetic expense of capturing and handling a capelin versus an Arctic cod is unknown. Generally, belugas seem to target larger, deeper Arctic cod and smaller, shallower capelin (Falk-Petersen et al. 1986, Brown 2002, Matley et al. 2015, Quakenbush et al. 2015). Overall, deeper dives to catch cod are energetically more expensive, but the payoff is large since these cod are larger in size, whereas catching smaller capelin in shallow waters requires a lower energy input, but results in a lower payoff as the fish are smaller. Thus, it is difficult to determine the impact a switch from capelin to Arctic cod would have on the energy budget of individual belugas, but we would expect it to be inconsequential, particularly since belugas in Hudson Bay have monopolized on capelin (Kelley et al. 2010), and capelin may also be an important dietary item for narwhals Monodon monoceros (Watt \& Ferguson 2015), the closest living relative of belugas.

Our understanding of diet for beluga whales in Cumberland Sound comes primarily from stable isotope and fatty acid analyses, but these techniques are unable to evaluate winter diet when samples are collected in the summer; for an understanding of winter diet we have to rely on dive information. Based on the dive information presented here, winter may be a particularly important time for deep benthic diving. Belugas in Cumberland Sound head just outside of the sound in the winter (Fig. 1), partly as a result of high sea ice concentrations in the region from
December to April (Brown et al. 2014), but their movements may also reflect dietary needs, and a possible candidate prey at this time is Greenland halibut. The commercial halibut fishery in Cumberland Sound currently operates in the winter season (Dennard et al. 2010) and thus may compete with beluga whales for resources at this time. An understanding of beluga diet and dive behaviour is needed to make informed conservation targets for Cumberland Sound belugas. Fatty acid data presented in our study seem to be reflecting changes that have been documented in the Cumberland Sound food web, and dive behaviour indicates that winter foraging may be particularly important for beluga whales.

Acknowledgements. All work was conducted under DFO Licence to Fish for Scientific Purposes, and prior approval was obtained from the Freshwater Institute Animal Care Committee (FWI-ACC-06-07-010, FWI-ACC-07-08-038, FWI-ACC-08-09-008), and followed approved protocols. We thank the many dedicated people in the research field camps for their valuable assistance with the handling and instrumenting of the beluga whales, and the Hunters and Trappers Organization in Pangnirtung, Nunavut, Canada, for all of their support. Thank you also to the many people who assisted with lab work for fatty acid analysis, particularly B. Rosenberg. Thanks also to S. Luque for running state space models on tag data. Thank you to 3 anonymous reviewers whose comments improved the final version of the manuscript. Fisheries and Oceans Canada, NSERC, Species at Risk, the Nunavut Wildlife Management Board, and ArcticNet provided funding.

\section{LITERATURE CITED}

Bailleul F, Lesage V, Power M, Doidge DW, Hammill MO (2012) Differences in diving and movement patterns of two groups of beluga whales in a changing Arctic environment reveal discrete populations. Endang Species Res 17:27-41

Box GEP, Cox DR (1964) An analysis of transformations. J R Stat Soc B 26:211-252

Brown ED (2002) Life history, distribution, and size structure of Pacific capelin in Prince William Sound and the northern Gulf of Alaska. ICES J Mar Sci 59:983-996

> Brown TA, Alexander C, Yurkowski DJ, Ferguson SH, Belt ST (2014) Identifying variable sea ice carbon contributions to the Arctic ecosystem: a case study using highly branched isoprenoid lipid biomarkers in Cumberland Sound ringed seals. Limnol Oceanogr 59:1581-1589

$>$ Budge SM, Iverson SJ, Koopman HN (2006) Studying trophic ecology in marine ecosystems using fatty acids: a primer on analysis and interpretation. Mar Mamm Sci 22: 759-801

Christiansen JS, Hop H, Nilssen EM, Joensen J (2012) Trophic ecology of sympatric Arctic gadoids, Arctogadus glacialis (Peters, 1872) and Boreogadus saida (Lepechin, 1774), in NE Greenland. Polar Biol 35:1247-1257

Citta JJ, Suydam RS, Wuakenbuch LT, Frost KJ, O'CorryCrowe GM (2013) Dive behaviour of eastern Chukchi 
beluga whales (Delphinapterus leucas), 1998-2008. Arctic 66:389-406

Cobb DG (2011) Identification of ecologically and biologically significant areas (EBSAs) in the Canadian Arctic. DFO Can Sci Advis Sec Res Doc 2011/070

COSEWIC (2004) COSEWIC assessment and update status report on the beluga whale Delphinapterus leucas in Canada. Committee on the Status of Endangered Wildlife in Canada, Ottawa

- Davis RW, Fuiman LA, Madden KM, Williams TM (2013) Classification and behavior of free-ranging Weddell seal dives based on three-dimensional movements and videorecorded observations. Deep-Sea Res II 88-89:65-77

> Dennard ST, McMeans BC, Fisk AT (2009) Preliminary assessment of Greenland halibut diet in Cumberland Sound using stable isotopes. Polar Biol 32:941-945

> Dennard ST, MacNeil MA, Treble MA, Campana S, Fisk AT (2010) Hierarchical analysis of a remote, Arctic, artisanal longline fishery. ICES J Mar Sci 67:41-51

DFO (2002) Cumberland Sound Beluga. DFO Sci Stock Status Rep E5-32(2002)

DFO (2005) Recovery potential assessment of Cumberland Sound, Ungava Bay, Eastern Hudson Bay and St. Lawrence beluga populations (Delphinapterus leucas). DFO Can Sci Advis Sec Sci Advis Rep 2005/036

DFO (2008) Cumberland Sound Greenland halibut (turbot) inshore fishery. DFO Can Sci Advis Sec Sci Advis Rep 2008/040

Falk-Petersen IB, Firvoll V, Gulliksen B, Haug T (1986) Occurrence and age/size relations of polar cod, Boreogadus saida (Lepechin), in Spitsbergen coastal waters. Sarsia 71:235-245

> Folch J, Lees M, Stanley GHS (1957) A simple method for the isolation and purification of total lipids from animal tissues. J Biol Chem 226:497-509

Gaston AJ, Woo K, Hipfner JM (2003) Trends in forage fish populations in northern Hudson Bay since 1981, as determined from the diet of nestling thick-billed murres Uria lomvia. Arctic 56:227-233

Greenhouse SW, Geisser S (1959) On methods in the analysis of profile data. Psychometrika 24:95-112

Hauser DDW, Laidre KL, Parker-Stetter SL, Horne JK, Suydam RS, Richard PR (2015) Regional diving behavior of Pacific Arctic beluga whales Delphinapterus leucas and possible associations with prey. Mar Ecol Prog Ser 541: 245-264

Heide-Jørgensen MP, Teilmann J (1994) Growth, reproduction, age structure and feeding habits of white whales (Delphinapterus leucas) in west Greenland waters. Medd Gronl Biosci 39:195-212

Heide-Jørgensen MP, Hammeken N, Dietz R, Orr J, Richard PR (2001) Surfacing times and dive rates for narwhals (Monodon monoceros) and belugas (Delphinapterus leuCas). Arctic 54:284-298

> Hop H, Gjøsæter H (2013) Polar cod (Boreogadus saida) and capelin (Mallous villosus) as key species in marine food webs of the Arctic and the Barents Sea. Mar Biol Res 9: 878-894

> Huntington HP, The Communities of Buckland, Elim, Koyuk, Point Lay and Shaktoolik (1999) Traditional knowledge of the ecology of beluga whales (Delphinapterus leucas) in the eastern Chukchi and northern Bering Seas, Alaska. Arctic 52:49-61

> Iverson SJ, Field C, Bowen WD, Blanchard W (2004) Quantitative fatty acid signature analysis: a new method of estimating predator diets. Ecol Monogr 74:211-235

Jakobsson M, Mayer L, Coakley B, Dowdeswell JA and others (2012) The International Bathymetric Chart of the Arctic Ocean (IBCAO) version 3.0. Geophys Res Lett 39: L12609

Jonsen ID, Mills Flemming J, Myers RA (2005) Robust statespace modeling of animal movement data. Ecology 86: 2874-2880

Kelley TC, Loseto LL, Stewart REA, Yurkowski M, Ferguson $\mathrm{SH}$ (2010) Importance of eating capelin: unique dietary habits of Hudson Bay beluga. In: Ferguson SH, Loseto LL, Mallory ML (eds) A little less Arctic: top predators in the world's largest northern inland sea, Hudson Bay. Springer-Verlag, New York, NY, p 53-69

Kenkel NC (2006) On selecting an appropriate multivariate analysis. Can J Plant Sci 86:663-676

> Kingsley MCS, Gosselin S, Sleno GA (2001) Movements and dive behaviour of belugas in northern Quebec. Arctic 54: 262-275

Kirsch PE, Iverson SJ, Bowen WD (2000) Effect of a low-fat diet on body composition and blubber fatty acids of captive juvenile harp seals (Phoca groenlandica). Physiol Biochem Zool 73:45-59

Laidre KL, Stirling I, Lowry LF, Wiig $\varnothing$, Heide-Jørgensen MP, Ferguson SH (2008) Quantifying the sensitivity of Arctic marine mammals to climate-induced habitat change. Ecol Appl 18:S97-S125

> Loseto LL, Stern GA, Connelly TL, Deibel D and others (2009) Summer diet of beluga whales inferred by fatty acid analysis of the eastern Beaufort Sea food web. J Exp Mar Biol Ecol 374:12-18

> Majewski AR, Walkusz W, Lynn BR, Atchison S, Eert J, Reist JD (2016) Distribution and diet of demersal Arctic cod, Boreogadus saida, in relation to habitat characteristics in the Canadian Beaufort Sea. Polar Biol 39: 1087-1098

Marcoux M, McMeans BC, Fisk AT, Ferguson SH (2012) Composition and temporal variation in the diet of beluga whales, derived from stable isotopes. Mar Ecol Prog Ser 471:283-291

Marcoux M, Young BG, Asselin NC, Watt CA, Dunn JB, Ferguson SH (2016) Estimate of Cumberland Sound beluga (Delphinapterus leucas) population size from the 2014 visual and photographic aerial survey. DFO Can Sci Advis Sec Res Doc 2016/037

> Martin AR, Smith TG (1992) Deep diving in wild, free-ranging beluga whales, Delphinapterus leucas. Can J Fish Aquat Sci 49:462-466

Martin AR, Smith TG (1999) Strategy and capability of wild belugas, Delphinapterus leucas, during deep, benthic diving. Can J Zool 77:1783-1793

Martin AR, Smith TG, Cox OP (1998) Dive form and function in belugas Delphinapterus leucas of the eastern Canadian High Arctic. Polar Biol 20:218-228

Matley JK, Fisk AT, Dick TA (2015) Foraging ecology of ringed seals (Pusa hispida), beluga whales (Delphinapterus leucas) and narwhals (Monodon monoceros) in the Canadian High Arctic determined by stomach content and stable isotope analysis. Polar Res 34:24295

> Mauchly JW (1940) Significance test for sphericity of $n$-variate normal population. Ann Math Stat 11:204-209

McKinney MA, McMeans BC, Tomy GT, Rosenberg B and others (2012) Trophic transfer of contaminants in a changing Arctic marine food web: Cumberland Sound, Nunavut, Canada. Environ Sci Technol 46:9914-9922 
Mitchell E, Reeves RR (1981) Catch history and cumulative estimates of initial population size of cetaceans in the eastern Arctic. Rep Int Whaling Comm 31:645-682

Olson CL (1974) Comparative robustness of six tests in multivariate analysis of variance. J Am Stat Assoc 69: 894-908

Orlova EL, Dolgov AV, Rudneva GB, Oganin IA, Konstantinova LL (2009) Trophic relations of capelin Mallotus villosus and polar cod Boreogadus saida in the Barents Sea as a factor of impact on the ecosystem. Deep-Sea Res II 56:2054-2067

Orr JR, Joe R, Evic D (2001) Capturing and handling of white whales (Delphinapterus leucas) in the Canadian Arctic for instrumentation and release. Arctic 54:299-304

Perovich DK, Richter-Menge JA (2009) Loss of sea ice in the Arctic. Annu Rev Mar Sci 1:417-441

Quakenbush LT, Suydam RS, Bruyan AL, Lowry LF, Frost KJ, Mahoney BA (2015) Diet of beluga whales, Delphinapterus leucas, in Alaska from stomach contents, MarchNovember. Mar Fish Rev 77:70-84

Richard PR (2013) Size and trend of the Cumberland Sound beluga whale population, 1990 to 2009. DFO Can Sci Advis Sec Res Doc 2012/159

Richard P, Stewart DB (2008) Information relevant to the identification of critical habitat for Cumberland Sound belugas (Delphinapterus leucas). DFO Can Sci Advis Sec Res Doc 2008/085.

Rikardsen AH, Dempson JB, Amundsen P-A, Bjorn PA, Finstad B, Jensen AJ (2007) Temporal variability in marine

Editorial responsibility: Louise Chilvers, Wellington, New Zealand feeding of sympatric Arctic charr and sea trout. J Fish Biol 70:837-852

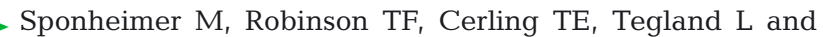
others (2006) Turnover of stable carbon isotopes in the muscle, liver, and breath $\mathrm{CO}_{2}$ of alpacas (Lama pacos). Rapid Commun Mass Spectrom 20:1395-1399

St. Aubin DJ, Smith TG, Geraci JR (1990) Seasonal epidermal molt in beluga whales, Delphinapterus leucas. Can J Zool 68:359-367

Tivy A, Howell SEL, Alt B, McCourt S and others (2011) Trends and variability in summer sea ice cover in the Canadian Arctic based on the Canadian Ice Service Digital Archive, 1960-2008 and 1968-2008. J Geophys Res 116:C03007

Ulrich K (2013) Trophic ecology of Arctic char (Salvelinus alpinus L.) in the Cumberland Sound region of the Canadian Arctic. MSc thesis, University of Manitoba, Winnipeg

Underwood AJ (1997) Experiments in ecology: their logical design and interpretation using analysis of variance. Cambridge University Press, Cambridge

Watt CA, Ferguson SH (2015) Fatty acids and stable isotopes $\left(\delta^{13} \mathrm{C}\right.$ and $\left.\delta^{15} \mathrm{~N}\right)$ reveal temporal changes in narwhal (Monodon monoceros) diet linked to migration patterns. Mar Mamm Sci 31:21-44

Watt CA, Orr JR, Heide-Jørgensen MP, Nielsen NH, Ferguson SH (2015) Differences in dive behaviour among the world's three narwhal Monodon monoceros populations correspond with dietary differences. Mar Ecol Prog Ser 525:273-285

Submitted: October 6, 2015; Accepted: August 18, 2016 Proofs received from author(s): November 1, 2016 